\title{
UJI DISINTEGRASI DAN DISOLUSI TERBANDING TABLET ALOPURINOL GENERIK BERMEREK DAN GENERIK BERLOGO YANG BEREDAR DI PASARAN
}

\author{
Anik Ariyani, Yandi Syukri, Bambang H. Nugroho* \\ Program Studi Farmasi Fakultas Matematika dan IImu Pengetahuan Alam \\ Universitas Islam Indonesia \\ *e-mail: b.hernawan@staff.uii.ac.id
}

\begin{abstract}
Allopurinol is a pyrimidine derivative that effective to normalize levels of uric acid in blood and urine. Allopurinol is very slightly soluble in water, but it has high permeability (BCS class II) so that the dissolution is an important determine to express the drug bioavailability. Additional material differences and the production process of each plant can cause differences in the quality of the resulting allopurinol tablets. This study aimed to compare the quality of branded generic and generic products allopurinol tablets in the quality of disintegration and dissolution. This study used 5 kinds branded generic ( $A, B, C, D, E)$ and 5 kinds of generic products $(F, G, H, I, J)$. Disintegration test carried out according to USP-NF $32^{\text {nd }}$ edition by the medium of water at $37 \pm 2{ }^{\circ} \mathrm{C}$. Dissolution tests conducted according to USP-NF $32^{\text {nd }}$ edition using apparatus 2 (paddle methode), the speed of rotation $75 \mathrm{rpm}$, in $0.01 \mathrm{~N} \mathrm{HCl}$ medium at $37 \pm 0.5^{\circ} \mathrm{C}$. The data obtained compared with the requirements listed in the Indonesia Pharmacopoeia $4^{\text {th }}$ edition and USP-NF $32^{\text {nd }}$ edition, and then statistically analyzed by $\mathrm{T}$ test at $95 \%$ confidence interval. Results of disintegration and dissolution tests met the requirements in the literature. Statistical test results showed that products had different disintegration and dissolution profile.
\end{abstract}

Keywords: allopurinol, disintegration, dissolution, tablets 